\title{
(2) \\ Ethnobotanical Study of Hyacinthaceae and Non-hyacinthaceous Geophytes in Selected Districts of Malawi
}

Research

\section{Abstract}

This paper reports on the findings of an ethnobotanical survey of geophytes used in 15 selected districts of Malawi. The survey was initially driven by the need to assess the conservation status and use of Lilioid monocots of the family Hyacinthaceae. Altogether, 49 geophytes were documented as useful for food (24\%), medicine $(58 \%)$ and other purposes (18\%). The most commonly reported species was Dioscorea odoratissima Pax. (Dioscoreaceae). Monocots represented $45 \%$ of the total. Members of the family Hyacinthaceae were only represented by $3(6 \%)$ species Albuca abyssinica Jacq., Ledebouria cordifolia (Baker) Stedje \& Thulin and Ledebouria revoluta (L.f.) Jessop. The study has further explored six alternative methods of evaluating sampling effort and estimating species richness. Michaelis-Menten Means estimator appeared to be the best estimator of species richness but was not able to accurately predict species richness for all the data combined. A bootstrap estimator was found to be more accurate. It was also apparent from the survey of geophytes that species in the Asteraceae and Fabaceae are more sought after for food and medicine than hyacinthoide monocots evidenced by fewer representatives mentioned by respondents.

\section{Introduction}

\section{The family Hyacinthaceae}

The family Hyacinthaceae formerly part of the monocotyledonous Liliaceae sensu lato (Engler \& Prantl 1930) was not accepted as a separate family until the work of Dahlgren (Dahlgren et al. 1985, Dahlgren \& Rasmussen 1983) and continues to be recognized as a distinct family (Angiosperm Phylogeny Group 2003, Stevens 2001). The family comprises \pm 40 genera and some 900 species widely distributed in temperate to tropical regions, with the highest diversity in southern Africa and in the re- gion from the Mediterranean to South-West Asia. (Stedje 1996a). Members of Hyacinthaceae occur in a great variety of habitats. Most species are adapted to seasonal climates that have a pronounced dry or cold period unfavorable for plant growth and during which the plants are dormant. Evergreen species are restricted to subtropical forests or savannah, temperate grasslands and perennially moist fynbos (Manning 2004). A few species grow in marshes or along streams and some even grow only in the spray of seasonal waterfalls. The above ground parts (leaves and stems) of deciduous species die down when the plant enters dormancy. The plants thus survive periods that are unfavorable for growth by retreating underground (Manning 2004).

Some members of the family Hyacinthaceae for example Drimia maritima (L.) Stern (synonym Urginea maritima (L.) Baker), the sea onion, has been in medicinal use since earliest times and was mentioned as early as 1554 B.C. in the Papyrus Ebers of the Middle Empire of Egypt as a cure for dropsy (Manning 2004). Bufadienolides isolated from $D$. maritima and Drimia indica (Roxb.) Jessop are cardioactive steroids that have digoxin-like effects

\section{Correspondence}

Elizabeth Mwafongo, National Herbarium, P.O. Box 528, Zomba, MALAWI. elizam@nhm.uio.no

Inger Nordal, Department of Biology, University of Oslo, P.O.Box 1045, Blindern N-0316, Oslo, NORWAY. inger.nordal@bio.uio. no

Zacharia Magombo, National Herbarium, P.O. Box 528, Zomba, MALAWl. zlkmagombo@hotmail.com,

Brita Stedje, Botanical Garden, Natural History Museum, University of Oslo, P.O. Box 1172, Blindern, N-0318 Oslo, NORWAY. brita.stedje@nhm.uio.no

Ethnobotany Research \& Applications 8:075-093 (2010)

Published: April 21, 2010 
(Manning et al. 2004). In South Africa, several species such as Ledebouria cooperi Jessop, Ledebouria inquinata Jessop, Ledebouria ovatifolia (Baker) Jessop, Ledebouria revoluta (L.f.) Jessop, Ornithogalum saundersiae Baker, Ornithogalum thyrsoides Jacq., and several members of subfamily Urgineoideae are poisonous to grazing animals (Manning 2004). The toxic compound (scilliroside, a bufadienolide) is used for poisoning rats (Pohl et al. 2000). In Malawi ethnobotanical uses are known for some members of the family, e.g., Albuca sp. from which an infusion is made of the roots that is drunk as a remedy for chest ailments (pneumonia) (Morris \& Msonthi 1991)

Hyacinthaceae are only occasionally used for human consumption. In Greece, the bulbs of Muscari comosum (L.) Mill. are eaten pickled, and in France, the inflorescences of Ornithogalum pyrenaicum L. are eaten as a vegetable (Pohl et al. 2000). In Africa, bushmen eat the bulbs of Ledebouria apertiflora Jessop and L. revoluta (Pohl et al. 2000). Hyacinthaceae are broadly employed for purposes ranging from the treatment of hangovers, rheumatic fever, sprains, syphilis and cancer, to the bewitchment of neighbors and securing of good fortune (Pohl et al. 2000). Many species feature prominently in the top ten regional medicinal plants in trade, the most important being Bowiea volubilis Harv. ex Hook.f. Eucomis autumnalis (Mill.) Chitt., and Scilla natalensis Planch. (Pohl et al. 2000). With 13 hyacinthaceous species identified from a total of 198 taxa catalogued in their medicinal plant survey, this family was second only to the Aloaceae in popularity in Southern Africa (Pohl et al. 2000).

More important is the use of various species of Hyacinthaceae as ornamentals and cut flowers. Species of $\mathrm{Ch}$ ouardia, Hyacinthoides, Hyacinthus, Muscari, Othocallis, Puschkinia, and Scilla are spring flowers of Northern Hemisphere parks and gardens. In southern Africa, species of Eucomis, Galtonia, Veltheimia and others are cultivated as ornamentals. Ornithogalum thyrsoides and related species are important as cut flowers (Manning 2004). In Malawi, some species of Ledebouria and Scilla are also used as ornamentals (personal observation).

\section{Geographical, Botanical and Demographic aspects}

Malawi (Figure 1) is situated in Central Africa between $9^{\circ}$ $22^{\prime}$ and $17^{\circ} 01^{\prime} \mathrm{S}$ and $32^{\circ} 43^{\prime}$ and $35^{\circ} 55^{\prime} \mathrm{E}$ (Mwanyambo \& Nihero 1998). It is divided into three administrative regions; Northern, Central and Southern. There are 26 districts. The Great Rift Valley traverses the country from north to south, and in this deep trough lie Lake Malawi, the third-largest lake in Africa, comprising about $20 \%$ of Malawi's area.

Malawi is a landlocked, densely populated country. Its economy is heavily dependent on agriculture which, represents $34.7 \%$ of the gross domestic product and represents about $80 \%$ of all exports. Nearly $90 \%$ of the population engages in subsistence farming (BAA 2008). The

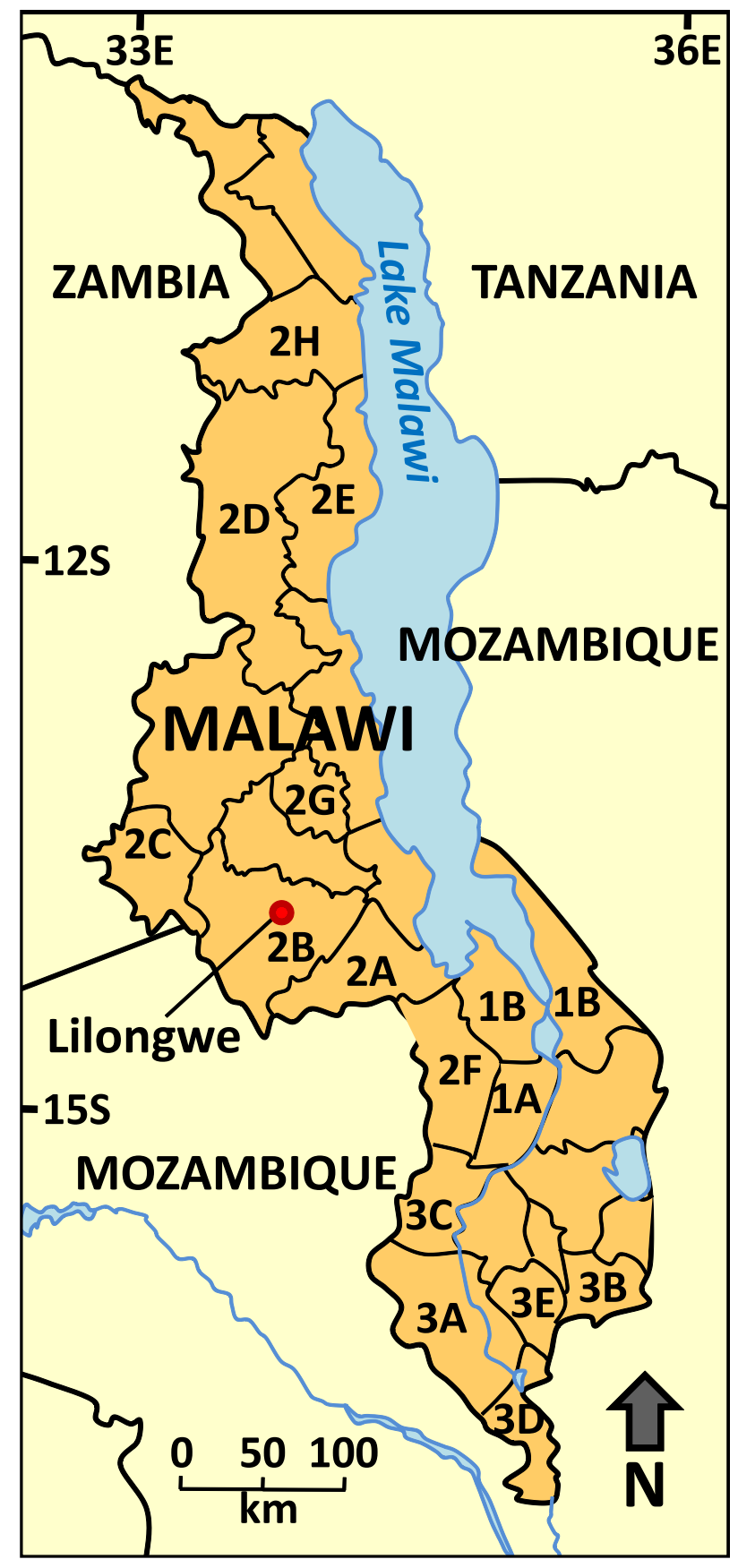

Figure 1. Malawi and the districts visited during the geophyte survey: 1A. Balaka, 1B. Mangochi ; 2A. Dedza, 2B. Lilongwe, 2C. Mchinji, 2D. Mzimba, 2E. Nkhata bay, 2F. Ntcheu, 2G. Ntchisi, 2H. Rumphi; 3A. Chikwawa, 3B. Mulanje, 3C. Mwanza, 3D. Nsanje, 3E. Thyolo.

agricultural sector contributes about $63.7 \%$ of total income for the rural population, $65 \%$ of manufacturing sector's raw materials, and approximately $87 \%$ of total employment (reviewed in Mwanyambo \& Nihero 1998). The population is presently estimated at 12 million of which $90 \%$ live in rural areas. Agricultural products account for $90 \%$ 


\section{Mwafongo et al. - Ethnobotanical Study of Hyacinthaceae and Non- hyacinthaceous Geophytes in Selected Districts of Malawi}

of Malawi's exports; tobacco, tea and cotton are the major export commodities (NSO 1992).

White (1976) proposed a chorological classification of African vegetation and Malawi falls within the Zambezian region. Floristically, Malawi is included in the Flora Zambesiaca region together with the following countries; Mozambique, Zambia, Zimbabwe, Botswana, and the Caprivi Strip of Namibia. It is known to be one of the richest in its specific diversity, and the main vegetation which characterizes this region is different forms of woodland and thicket lacking evergreen rain forests (White et al. 2001). Zambezian woodlands comprise three major types: 1 . miombo (dominated by Brachystegia spp.), 2. mopane (dominated by Colophospermum mopane (J. Kirk ex Benth.) J. Léonard), and 3. undifferentiated woodland. The total number of plant species in Malawi is estimated at between 55006000 (Msekandiana \& Mlangeni 2002). Malawi presents a rich mosaic of different habitats brought about by its varied topography and altitudinal ranges $(37-3002 \mathrm{~m})$ and rainfall regimes with the average rainfall ranging from 700 to $3000 \mathrm{~mm}$ (White et al. 2001). From May to August, the climate is cool and dry. Average temperatures rise from September to November and the rainy season begins towards the end of November and extends to April or May (NSO 1992).

The populations of developing countries worldwide continue to rely on the use of wild plants as a source of food and traditional medicine as their primary source of health care. This has created a demand for forest products, which cannot be met from rapidly dwindling indigenous forests (Hardcastle 1977). Ethnobotanical surveys conducted throughout Africa confirm that native plants are the main constituent of traditional African medicines (reviewed in Cunningham 1993). With $70-80 \%$ of Africa's population relying on traditional medicines, the importance of the role of medicinal plants in the health care system is enormous (Cunningham 1993). Mwanyambo \& Nihero (1998) noted that, in Malawi, modern health care provided principally by Ministry of Health and Population (MOHP) is highly complemented by services from herbalists especially in the rural areas where $90 \%$ of the population lives. Herbalists are the people, who handle most local health problems. On a national scale, there is one herbalist to every 138 persons. This is in contrast to a doctor to population ratio of $1: 27,000$ and a nurse to population ratio of $1: 14,000$ for the period 1985-1990 (Anon. 1997).

Interest in ethnobotany of Malawian plants dates back to the 1970s with a benchmark study by Williamson (1974). In his book, he documented useful plants of Malawi. This was the first comprehensive study of all useful plants of Malawi as a nation, and in her book she listed 122 plant species. Other notable investigations are generally on the use of medicinal plants in Malawi (Hagreaves 1994, Maliwichi 1997, Morris \& Msonthi 1996, Msonthi 1994, Msonthi \& Seyani 1994, Mwanyambo \& Nihero 1998, Ndibwami et al. 1998) as well as non-medicinal plant uses of the other tribes of Malawi (Mwanyambo 1994). The study by Mwanyambo \& Kananji (2001) on edible tubers lists some of the species that are edible especially during famine and some eaten in the form of relish. The list includes the orchids Satyrium buchananii Schltr. and Satyrium sp. (both locally known as mbuyeuye, a Nyanja term which refers to a type of vegetation with Brachystegia and Jubernadia), Satyrium carsonii Rolfe, Disa robusta N.E.Br. and Disa ukingensis Schltr.

The urgent need to carry out ethnobotanical surveys in Malawi has been expressed by several workers (reviewed in Mwanyambo 1994) because of concern about steady loss of plants and tribal traditions through decline in natural vegetation and urbanization. The present study, therefore, addresses this issue by focusing on the geophytic flora, with particular emphasis on Hyacinthaceae.

Geophytes are plants which posses underground resting buds attached to storage organs such as rhizomes, tubers, bulbs or corms (Esler et al. 1999) but in this study, only bulbs and tubers are considered. A tuber is a thickened underground stem, and the stem tissue serves as the primary storage tissue; but unlike a corm, it has no basal plate. Meristems occur on the tuber and are commonly called "eyes" on a potato. A true bulb is comprised of a compressed stem, or basal plate, and modified leaves called scales serve as the primary storage tissue. Examples include tulip, lily, allium (e.g., onion). In the present study the collective term 'underground parts' will be used to refer to both bulbs and tubers

Although some geophytes are known to be evergreen, many of them survive periods of environmental stress such as summer drought or winter cold by dying back to these underground storage organs (Dafni et al. 1981). When the conditions are favorable, they resprout new foliage with inflorescences imaging before, during or at the end of the vegetative growing season. Geophytes are generally targeted by people for food, medicine and ornamentals. This act causes serious damage to the targeted plants and in most cases the whole plant is uprooted and dies back. Although few data are available on the impact of harvesting underground organs, i.e., whole plants, local depletion of plants targeted has been recorded elsewhere (reviewed in Cunningham 1994). The present investigation sought to document ethnobotanical uses of geophytes of the family Hyacinthaceae but since no previous ethnobotanical work has been done exclusively on geophytes of Malawi, this also included non-Lilioid plants to gain an overview of their use and to assess their conservation status. Furthermore, the study explored methods of measuring sampling effort and species richness among the 15 selected districts using non-parametric methods adapted from mark-recapture applications for estimating population size (reviewed in Williams et al. 2007). These methods require no assumptions about community structure (Colwell \& Coddington 1995). The estimators are also known to be homologous in that richness is estimated from the preponderance of 
rare species (Colwell \& Coddington 1994), i.e., the higher the proportional abundance of rare species, the greater the probability of encountering more new species with increased sampling effort (Williams et al. 2007).

\section{Methodology}

An understanding of geophyte use in Malawi and their conservation status required the administration of group and household interviews through the administration of a structured questionnaire. The survey was conducted from the period January to March 2007 in three phases; Phase 1 (Mangochi and Balaka Districts); Phase 2 (Rumphi, Mzimba, Nkhatabay, Ntchisi, Mchinji, Lilongwe, Dedza, Ntcheu Districts) and Phase 3 (Nsanje Chikwawa, Mwanza, Mulanje and Thyolo Districts). See Figure 1 for list of the districts numbered in phase order. Phase 1 was conducted to pretest the designed questionnaire and adjustments were made to some of the questions before going into the second phase. All in all, 87 questionnaires were administered in the 15 selected districts mostly to individuals and in some cases to groups. The districts were selected to include different tribes represented in Malawi. Data collected included personal particulars, knowledge of geophytes and uses. To asses the economic significance and conservation status of geophytes data on cost and availability was also collected. Plants names were recorded on site and both scientific and vernacular names recorded. All names were verified at National Herbarium in Zomba by technicians.

Data analysis was achieved by using three programs; Microsoft Excel 2003, PAST (Hammer \& Harper 2004) and EstimateSWin800 (Colwell 2006). Microsoft Excel was used for univariate analysis whereas PAST was employed for cluster analysis. Cluster analysis is a family of multivariate statistics which attempts to subdivide or partition a set of heterogeneous objects into relatively homogenous groups (Höft et al. 1999). Dice similarity index, also known as Sorensen Index, was used in the clustering analysis. This index is useful for calculating the similarity index of presence/absence or positive/negative reply data (qualitative) (Höft et al. 1999). The mathematical algorithm calculates the degree of similarity or dissimilarity and clusters the objects according to their overall most similar attributes, i.e., it projects clusters of objects that are more similar to each other than any other specimen (Sneath \& Sokal 1973). Data on presence/absence of species collected from all the districts were used in the cluster analysis and the resultant table of similarity indexes were projected as a dendrogram.
EstimateS (Colwell 2006) was used to plot a species accumulation curve/collectors curve, which is a plot of cumulative number of species discovered within a defined area as a function of some measure of the effort expended to find them (Colwell \& Coddington 1994). According to Williams et al. (2007), if sampling is incomplete, the curve will show an upward trend illustrating the extent to which sampling effort might have to be increased to accumulate more species. Six non-parametric species richness estimators, namely: ICE, Chao 2, first order and secondorder Jackknife, bootstrap and Michaelis-Menten Means, appropriate for incidence-based data (observed species) were run to evaluate their performance in estimating species richness. The sample order was randomized 100 times to compute the mean estimator and expected species richness for each sample accumulation level the end result of which was a smooth curve. The 15 districts visited are here treated as samples. A thorough description and formulae of the species richness estimators used in the present are well documented in Colwell \& Coddington (1994).

\section{Results}

Fifty nine percent of people interviewed in the survey were female. Most respondents were from the Sena tribe (30\%), and the least proportion from Yao tribe (4\%) (Figure 2). Regarding age groups of respondents, $18 \%$ were over 50 years old, over half of them, $52 \%$ were $35-49$ years old, $26 \%$ were $21-34$ years old, and the least proportion, $2 \%$ were less than 20 years old.

Table 1 summarizes the results of interviews about plants. When asked if they were familiar with geophytes around them, the majority (88\%) indicated that they were familiar

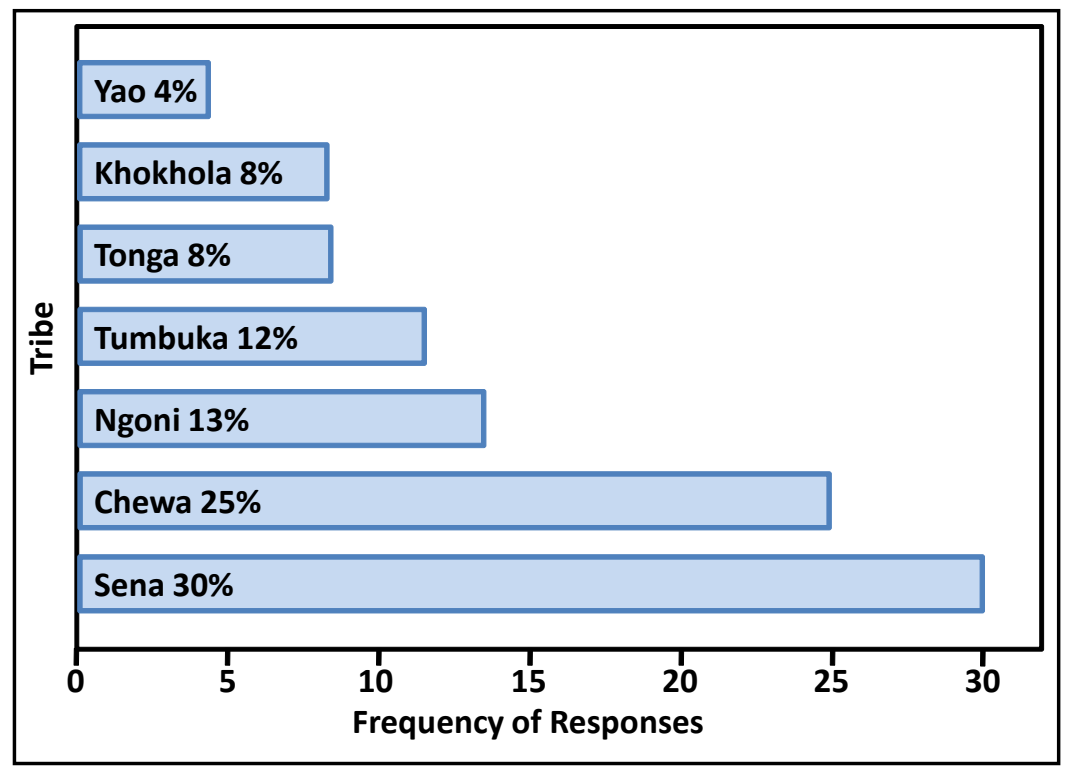

Figure 2. Percentage of respondents based on tribe as interviewed in Malawi about familiarity with geophytes. 
Mwafongo et al. - Ethnobotanical Study of Hyacinthaceae and Nonhyacinthaceous Geophytes in Selected Districts of Malawi

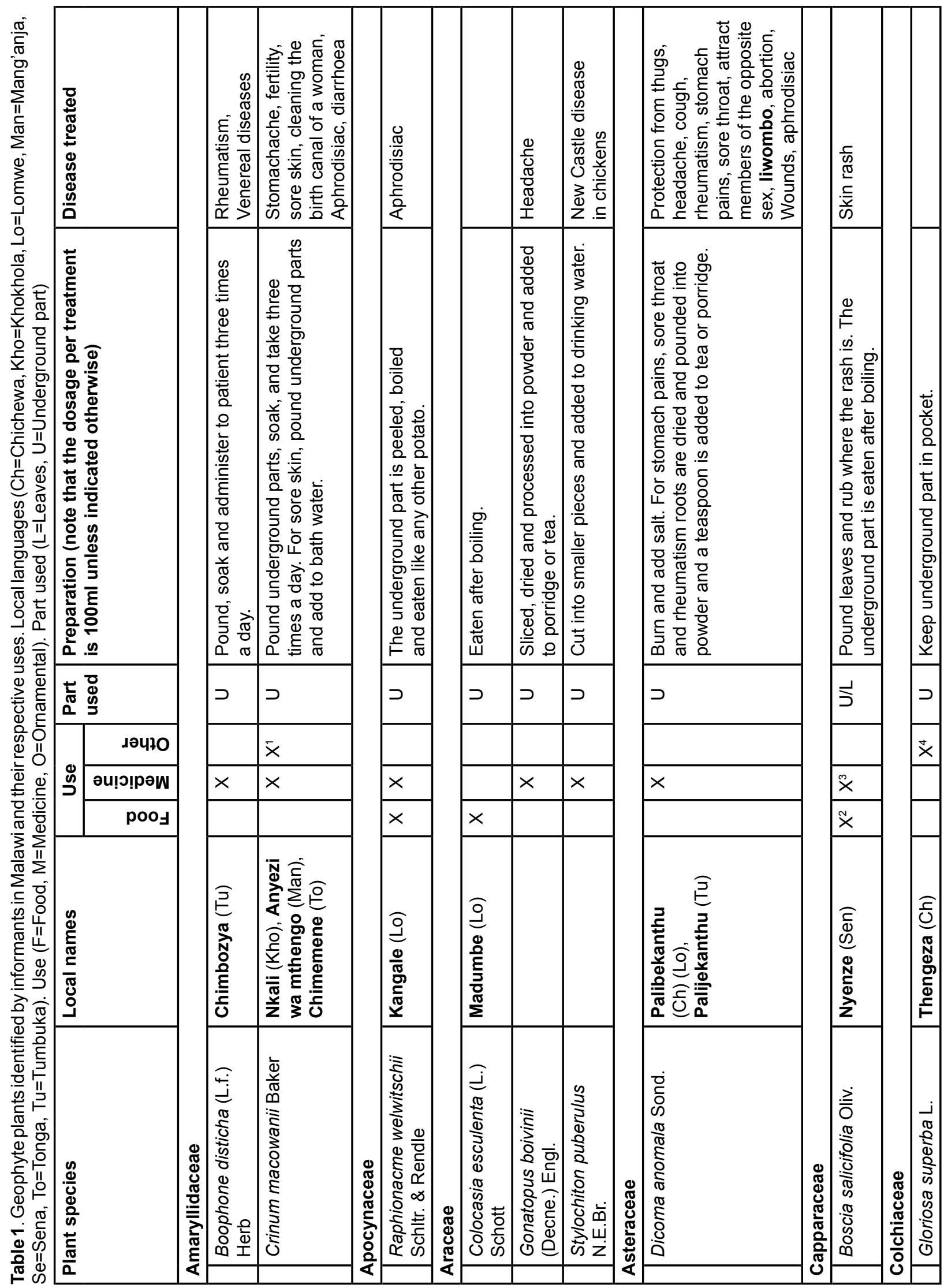

www.ethnobotanyjournal.org/vol8/i1547-3465-08-075.pdf 


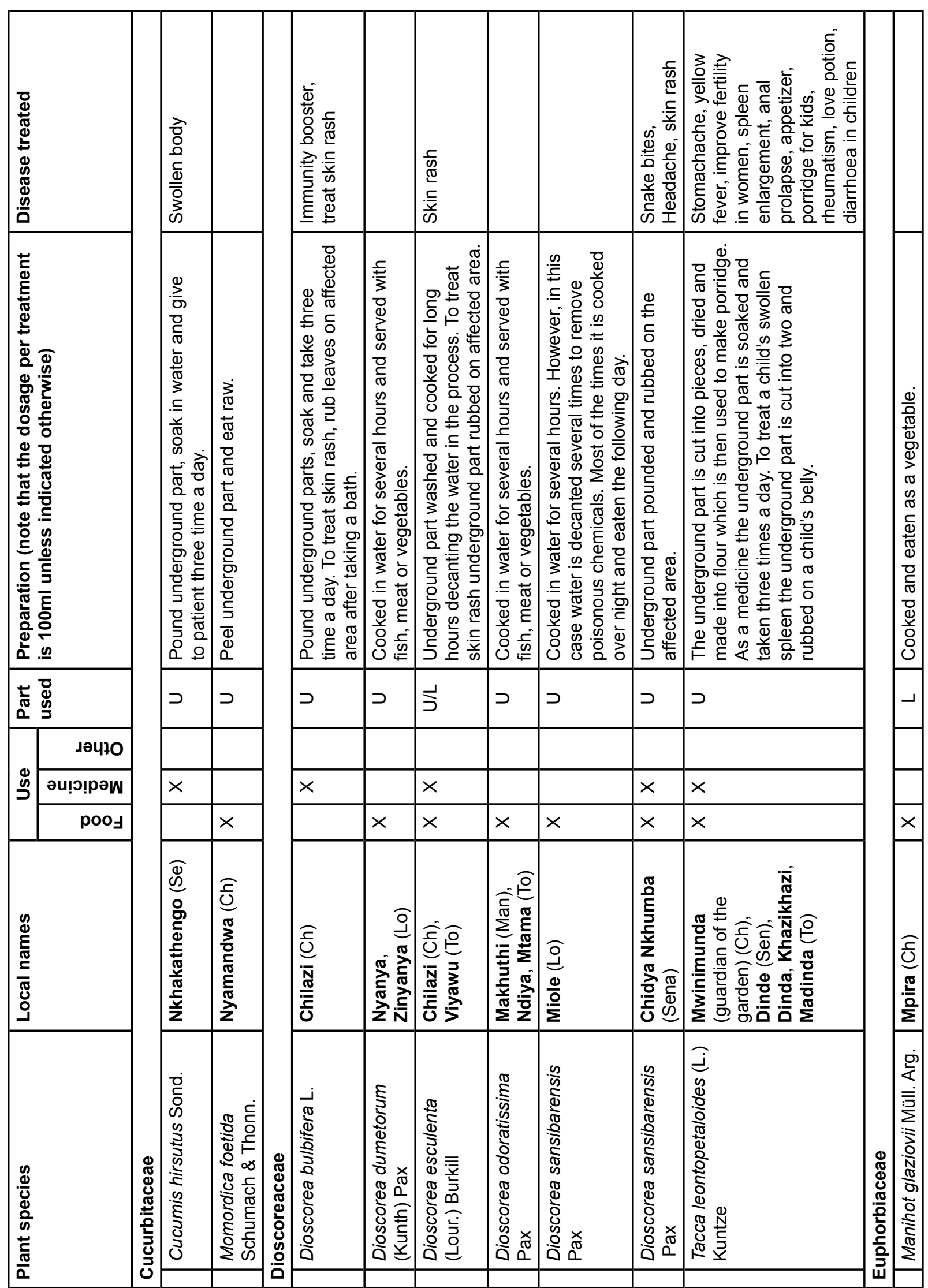


Mwafongo et al. - Ethnobotanical Study of Hyacinthaceae and Nonhyacinthaceous Geophytes in Selected Districts of Malawi

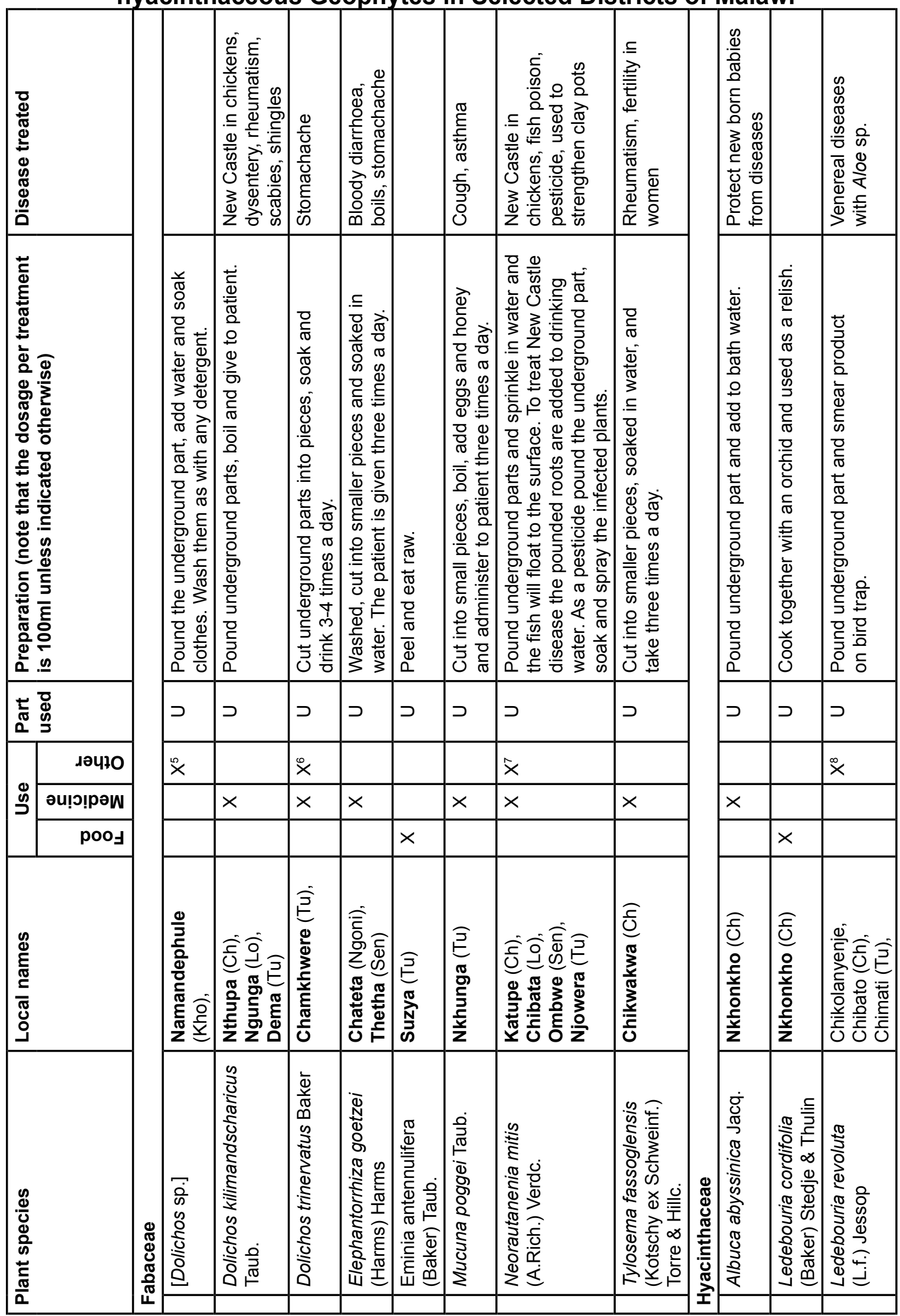

www.ethnobotanyjournal.org/vol8/i1547-3465-08-075.pdf 


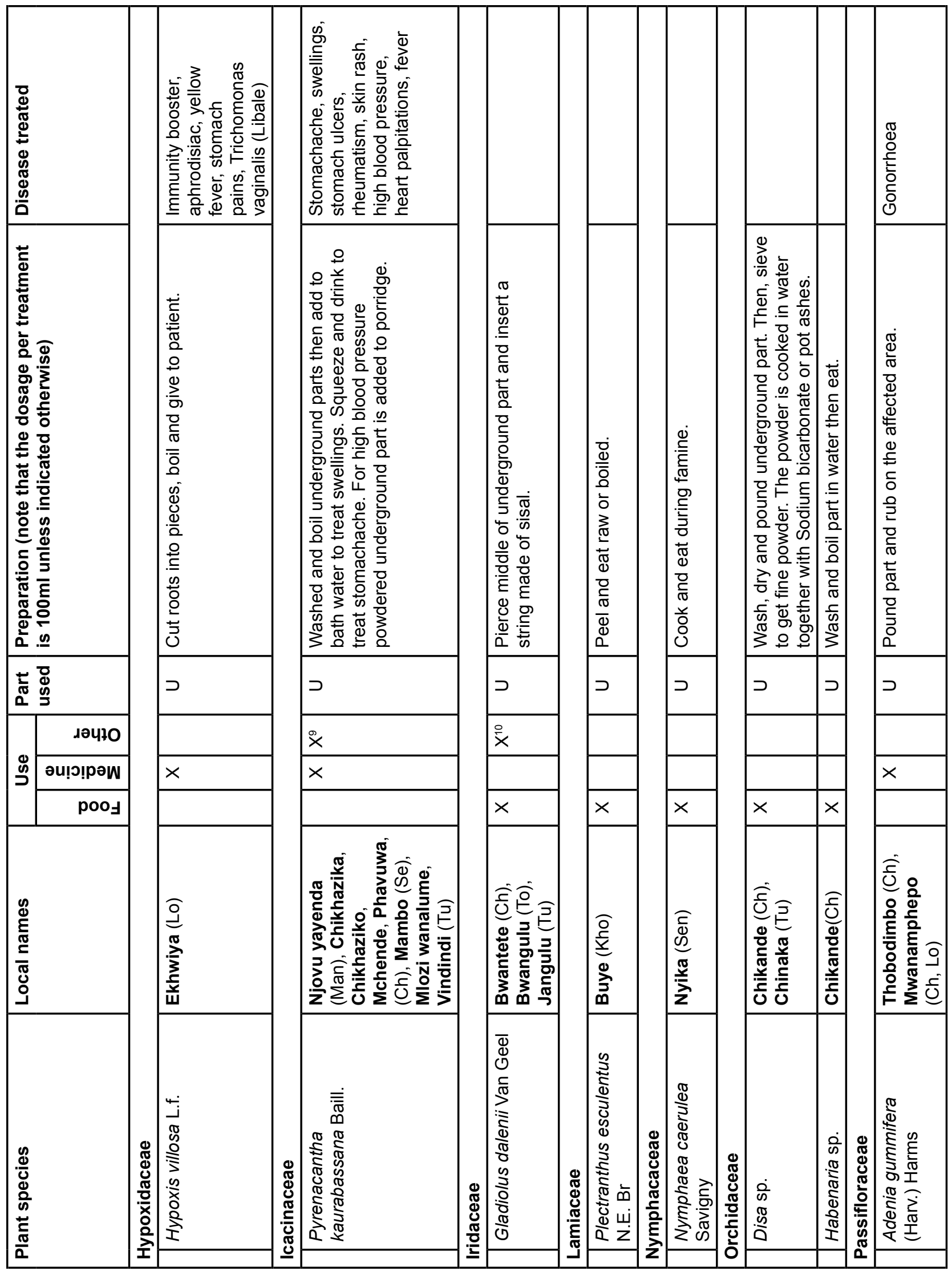


Mwafongo et al. - Ethnobotanical Study of Hyacinthaceae and Nonhyacinthaceous Geophytes in Selected Districts of Malawi

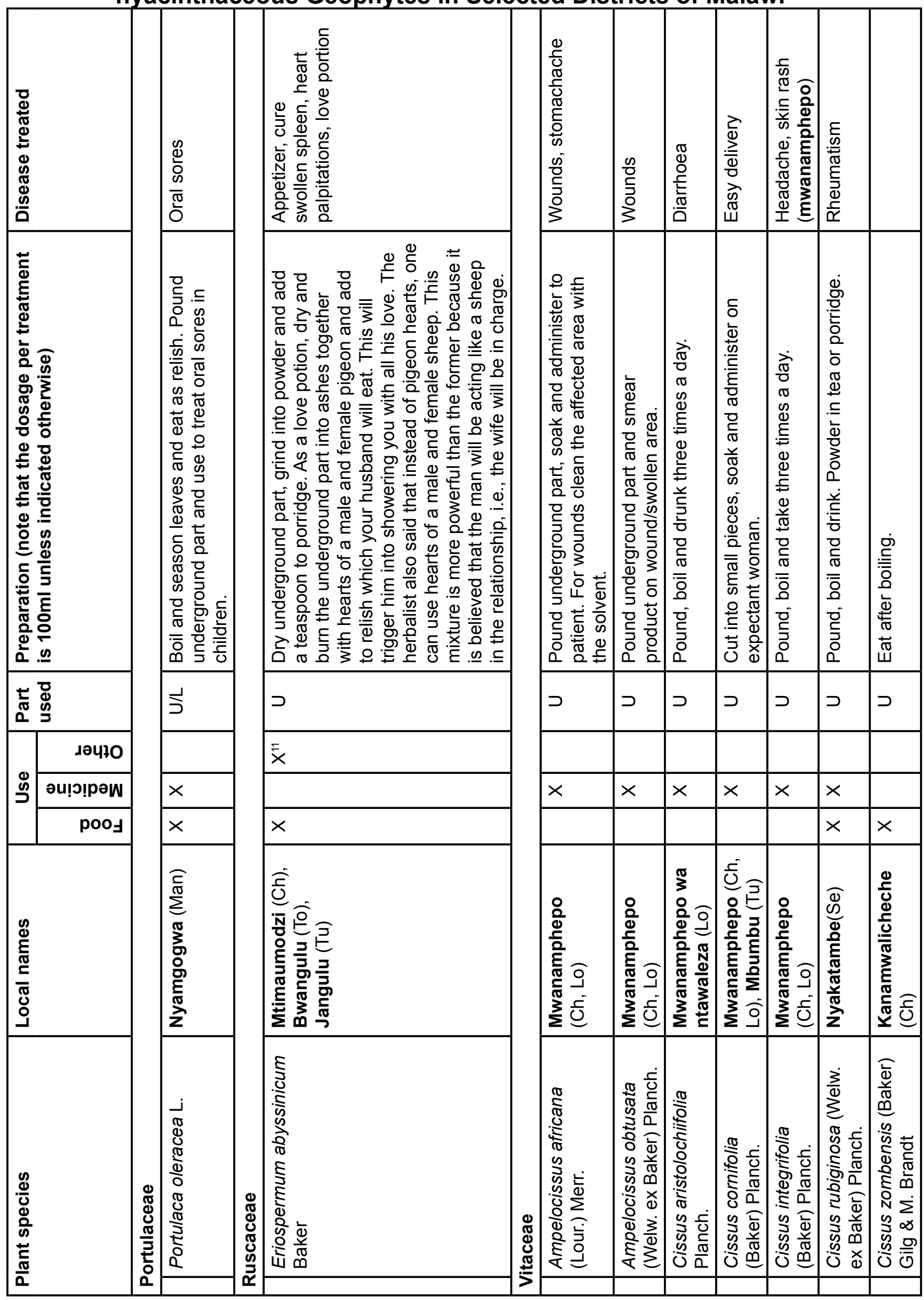




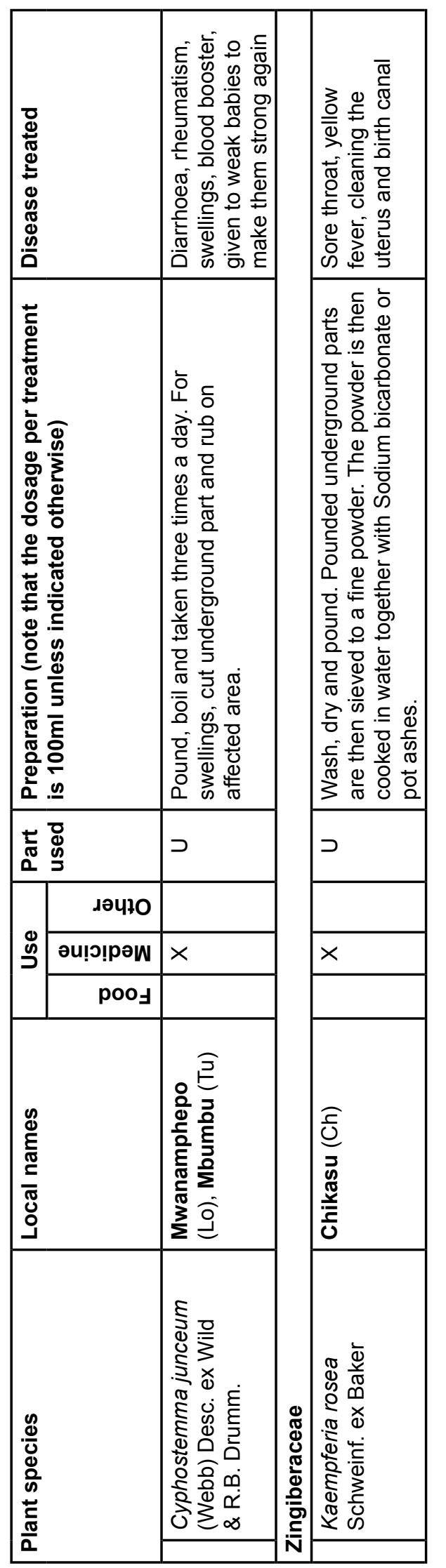

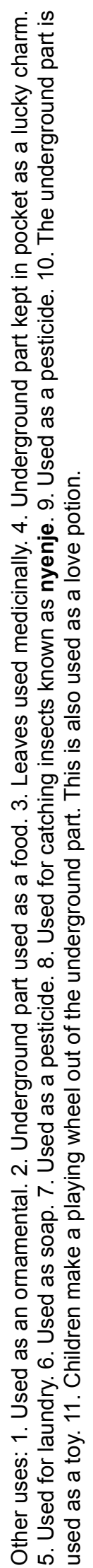

with the plants. Those who were not familiar (12\%) were all between age 21 and 49 . A total of 49 species were recorded in the survey as being used by the respondents either for food $(24 \%)$, medicine $(18 \%)$, or other uses $(58 \%)$ including as ornamentals, pesticides, for child's play and laundry. Figure 3 illustrates the eight most commonly reported or popular geophytes reported with other species mentioned fewer times. Plant parts used were reported as either leaves only (4\%), leaves and underground parts $(6 \%)$ or underground parts $(90 \%)$. Prescriptions for preparation of remedies and diseases treated were also recorded (Table 1). The 49 species listed were lumped into three major use categories (food, medicinal and other) and then further grouped into 16 use categories (Table 2).

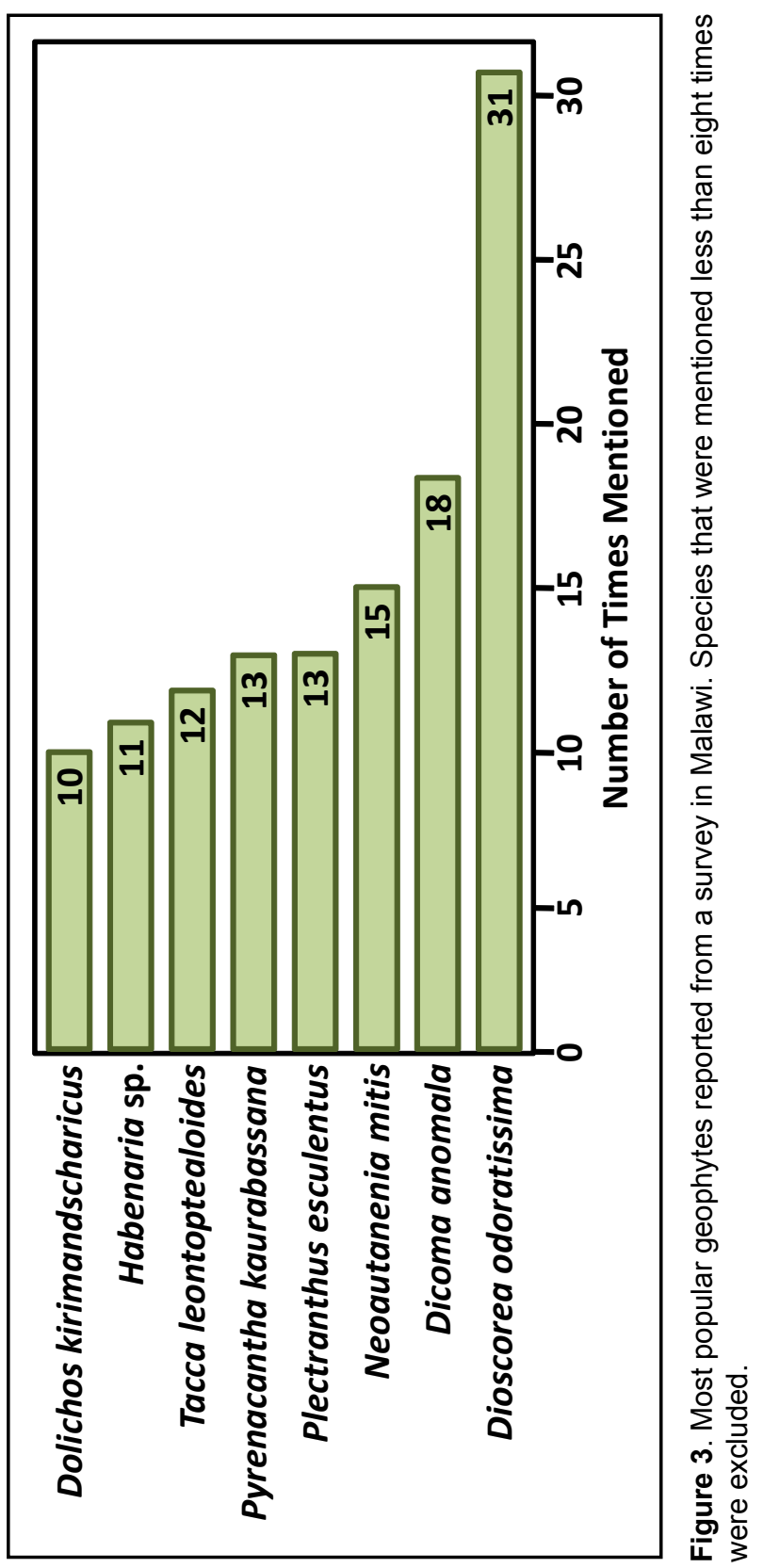


Mwafongo et al. - Ethnobotanical Study of Hyacinthaceae and Non-
hyacinthaceous Geophytes in Selected Districts of Malawi

Table 2. Medicinal geophytes identified by informants in Malawi and sorted into major use categories. (See Figure 5.)

\begin{tabular}{|c|c|c|c|c|c|c|c|c|c|c|c|c|c|c|c|c|}
\hline \multirow[t]{2}{*}{ Species } & \multicolumn{16}{|c|}{ Medicinal Use Categories } \\
\hline & $\begin{array}{l}\text { 응 } \\
\text { 누 }\end{array}$ & 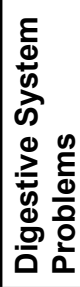 & 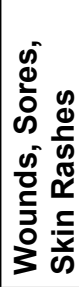 & 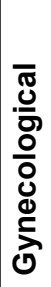 & 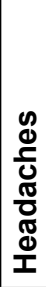 & 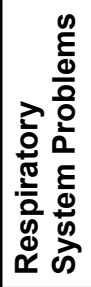 & 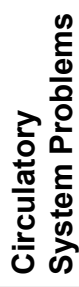 & 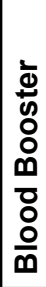 & 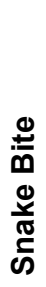 & 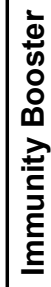 & 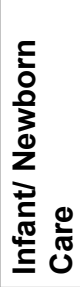 & 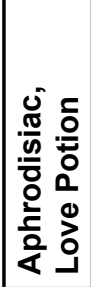 & 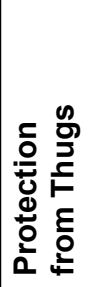 & 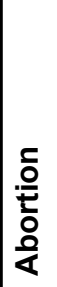 & 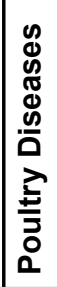 & 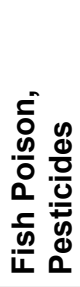 \\
\hline Adenia gummifera & & & & $X$ & & & & & & & & & & & & \\
\hline Albuca abyssinica & & & & & & & & & & & $X$ & & & & & \\
\hline Ampelocissus africana & & $X$ & $X$ & & & & & & & & & & & & & \\
\hline Ampelocissus obtusata & & & $\mathrm{X}$ & & & & & & & & & & & & & \\
\hline Boophane disticha & & & & $X$ & & & $X$ & & & & & & & & & \\
\hline Boscia salicifolia & & & $X$ & & & & & & & & & & & & & \\
\hline Cissus aristolochiifolia & & $X$ & & & & & & & & & & & & & & \\
\hline Cissus comifolia & & & & $\mathrm{X}$ & & & & & & & & & & & & \\
\hline Cissus integrifolia & & & $X$ & & $X$ & & & & & & & & & & & \\
\hline Cissus rubiginosa & $X$ & & & & & & $\mathrm{X}$ & & & & & & & & & \\
\hline Cissus zombensis & $X$ & & & & & & & & & & & & & & & \\
\hline Colocasia esculenta & $X$ & & & & & & & & & & & & & & & \\
\hline Crinum macowanii & & $X$ & $X$ & $X$ & & & $X$ & & & & & $X$ & & & & \\
\hline Cucumis hirsutus & & & & & & & $\mathrm{X}$ & & & & & & & & & \\
\hline Cyphostemma junceum & & $\mathrm{X}$ & & & & & $X$ & $\mathrm{x}$ & & & $\mathrm{X}$ & & & & & \\
\hline Dicoma anomala & & $X$ & $X$ & & $X$ & $\mathrm{X}$ & $X$ & & & & & $X$ & $\mathrm{X}$ & $\mathrm{X}$ & & \\
\hline Dioscorea bulbifera & & & $X$ & & & & & & & $\mathrm{X}$ & & & & & & \\
\hline Dioscorea dumetorum & $X$ & & & & & & & & & & & & & & & \\
\hline Dioscorea esculenta & $X$ & & & & & & & & & & & & & & & \\
\hline Dioscorea odoratissima & $X$ & & & & & & & & & & & & & & & \\
\hline Dioscorea sansibarensis & $X$ & & $\mathrm{X}$ & & $\mathrm{X}$ & & & & $\mathrm{X}$ & & & & & & & \\
\hline Disa sp. & $X$ & & & & & & & & & & & & & & & \\
\hline Dolichos sp. & & $X$ & & & & & & & & & & & & & & \\
\hline Dolichos kilimandscharicus & & $X$ & $X$ & & & & $X$ & & & & & & & & $x$ & \\
\hline Dolichos trinervatus & & $\mathrm{X}$ & & & & & & & & & & & & & & \\
\hline Elephantorrhiza goetzei & & $X$ & $X$ & & & & $X$ & & & & & & & & & \\
\hline Eminia antennulifera & $X$ & & & & & & & & & & & & & & & \\
\hline Eriospermum abyssinicum & & $\mathrm{X}$ & & & & & & & & & & $\mathrm{X}$ & & & & \\
\hline Gladiolus dalenii & $X$ & & & & & & & & & & & & & & & \\
\hline Gloriosa superba & $X$ & & & & & & & & & & & & & & & \\
\hline Gonatopus boivinii & & & & & $X$ & & & & & & & & & & & \\
\hline Habenaria sp. & $X$ & & & & & & & & & & & & & & & \\
\hline Hypoxis villosa & & $\mathrm{X}$ & & $\mathrm{X}$ & & & $\mathrm{X}$ & & & $\mathrm{X}$ & & & & & & \\
\hline Kaempferia rosea & & & & $\mathrm{X}$ & & $X$ & $\mathrm{X}$ & & & & & & & & & \\
\hline Ledebouria cordifolia & $X$ & & & & & & & & & & & & & & & \\
\hline
\end{tabular}




\begin{tabular}{|c|c|c|c|c|c|c|c|c|c|c|c|c|c|c|c|c|}
\hline \multirow[t]{2}{*}{ Species } & \multicolumn{16}{|c|}{ Medicinal Use Categories } \\
\hline & $\begin{array}{l}\text { 웅 } \\
\text { 운 }\end{array}$ & 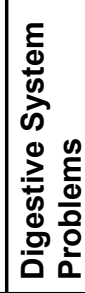 & 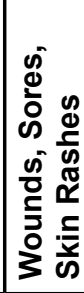 & 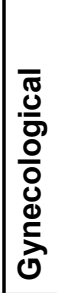 & 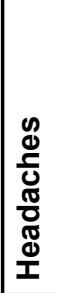 & 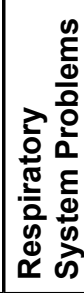 & 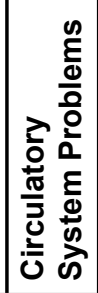 & 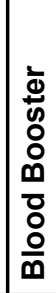 & 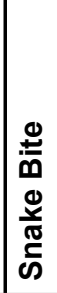 & 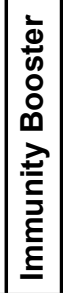 & 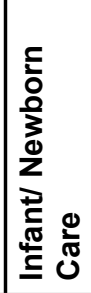 & 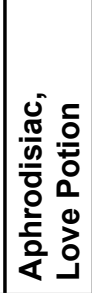 & 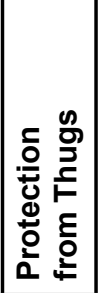 & 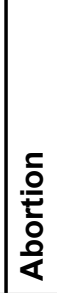 & 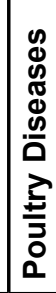 & 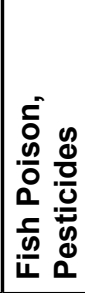 \\
\hline Ledebouria revoluta & & & & $x$ & & & & & & & & & & & & \\
\hline Manihot glaziovii & $x$ & & & & & & & & & & & & & & & \\
\hline Momordica foetida & $x$ & & & & & & & & & & & & & & & \\
\hline Mucuna poggei & & & & & & $\mathrm{x}$ & & & & & & & & & & \\
\hline Neorautanenia mitis & & & & & & & & & & & & & & & $\mathrm{x}$ & $x$ \\
\hline Nymphaea caerulea & $x$ & & & & & & & & & & & & & & & \\
\hline Plectranthus esculentus & $x$ & & & & & & & & & & & & & & & \\
\hline Portulaca oleracea & $x$ & & $x$ & & & & & & & & & & & & & \\
\hline Pyrenacantha kaurabassana & & $x$ & $x$ & & & & $x$ & & & & & & & & & \\
\hline Raphionacme we/witschii & $x$ & & & & & & & & & & & $x$ & & & & \\
\hline Stylochiton puperulus & & & & & & & & & & & & & & & $\mathrm{x}$ & \\
\hline Tacca leontopetaloides & $x$ & & & $x$ & & & $x$ & $x$ & & & $x$ & $x$ & & & & \\
\hline Tylosema fassoglensis & & & & $x$ & & & & & & & & & & & & \\
\hline
\end{tabular}

\section{Food Plants}

A number of geophyte species are used for food (24\%) being consumed raw or boiled in water. The only member of the family Hyacinthaceae which falls into this category is $L$. cordifolia. This bulb is mixed together with orchid tubers to make cakes that are used as relish. Five species of yams (Dioscorea) are however the mostly targeted for their tubers especially during periods of famine. Dioscorea odoratissima was frequently mentioned by respondents as being the most important tuber species (Figure 3), meaning that it was preferred over the other tuber species. Dioscorea species are known to have varying proportions of an alkaloid dioscorine that is bitter and toxic (Mwanyambo \& Kananji 2001). This is why some species known to be poisonous are cooked for long hours mostly overnight to remove toxicity. Water is decanted several times in the process of cooking. Another popular famine tuber is Nymphaea caerulea, locally known as nyika (Sena). The underground part is yam-like and the most popular famine food amongst the Sena people in Nsanje district. This species is very scarce such that men must travel by boat for six hours across the Shire River to harvest it because it has been over-exploited and hence scarce (Mpaka 2008). It is harvested underwater by diving. It is peeled and boiled before consuming. It is served together with vegetables. However, people complain that the underground part is bitter. Other tubers are eaten raw. These include Eminia antennulifera, Momordica foetida and Plectranthus esculentus.
Medicinal plants

The 29 geophyte species identified as medicinal are mostly used in preparations which are powders, decoctions and ashes (Figure 4). In this category, the only members of the family Hyacinthaceae mentioned were Albuca abyssinica and $L$. revoluta. Dicoma anomala was mentioned as the most popular medicinal plant (Figure 3 ) by respondents because of its diverse uses. Figure 5 sorts the diseases treated by the underground parts of the plants reported into major use categories. Interestingly, half of the uses account for the three largest categories with $17 \%$ each.

Some members of the genus Hypoxis, commercially known as "African potato," are taken to boost the immune system especially by people infected with HIV (Ncube 1998). In the category of boosting the immunity of human beings, especially those infected with AIDS, the geophytes involved are used in combination with other tubers and the end product of this is administered in powder form. One of the respondents, a traditional healer claimed that the drug (Figure 4A), which is a combination of several tuber species "has been proven to purify blood and raise the CD4 cell count of patients suffering from AIDS" and further claimed that "most patients had gained weight after taking the drug." The vast number of medicinal plant species as opposed to food species is an indication of the important role played by geophytes in the health care system of Malawi. 
Mwafongo et al. - Ethnobotanical Study of Hyacinthaceae and Nonhyacinthaceous Geophytes in Selected Districts of Malawi

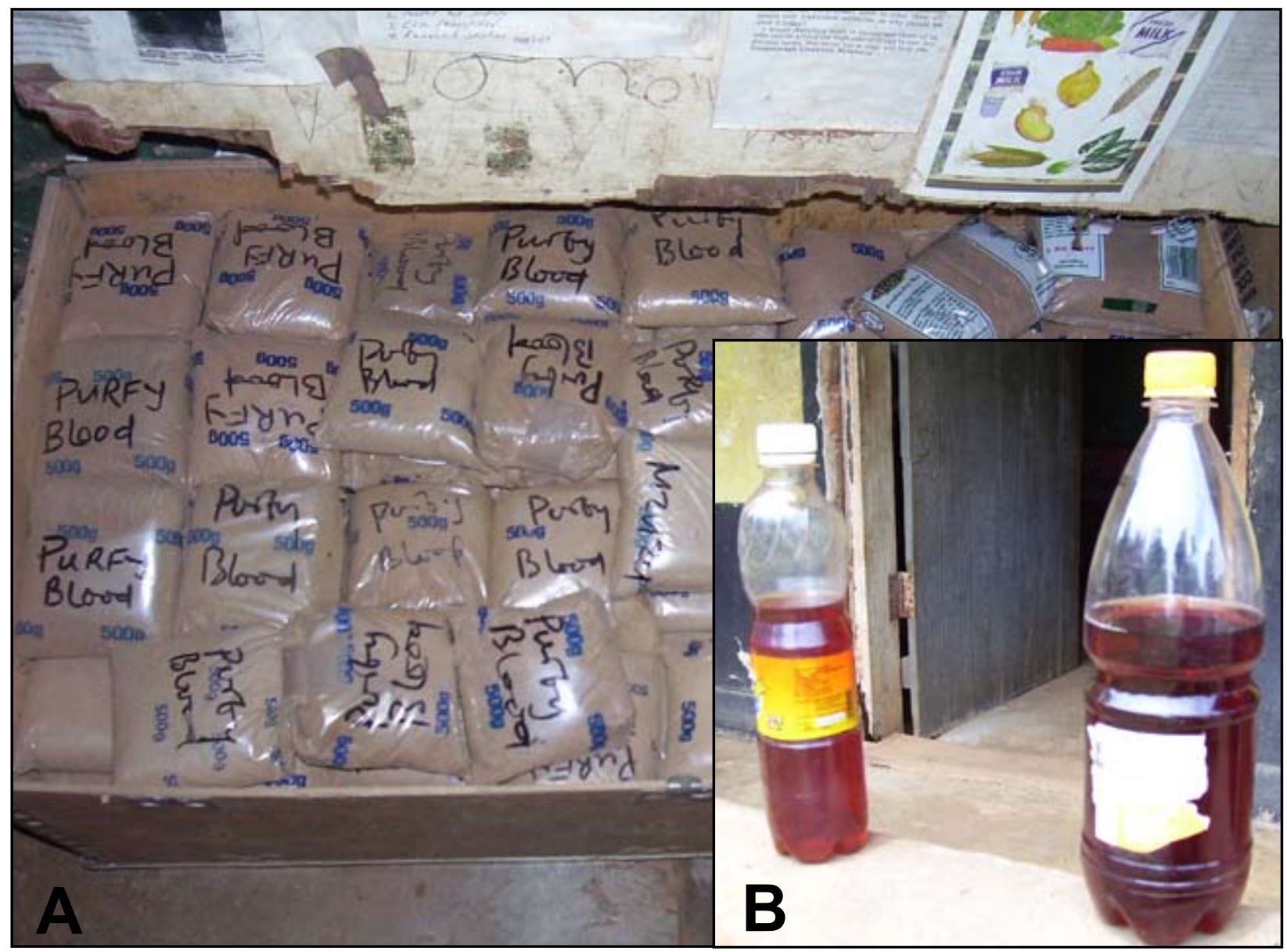

Figure 4. Geophyte-based remedies documented in Malawi are usually prepared in the form of (A) powders and (B) decoctions. (Photos by D. Mpalika)

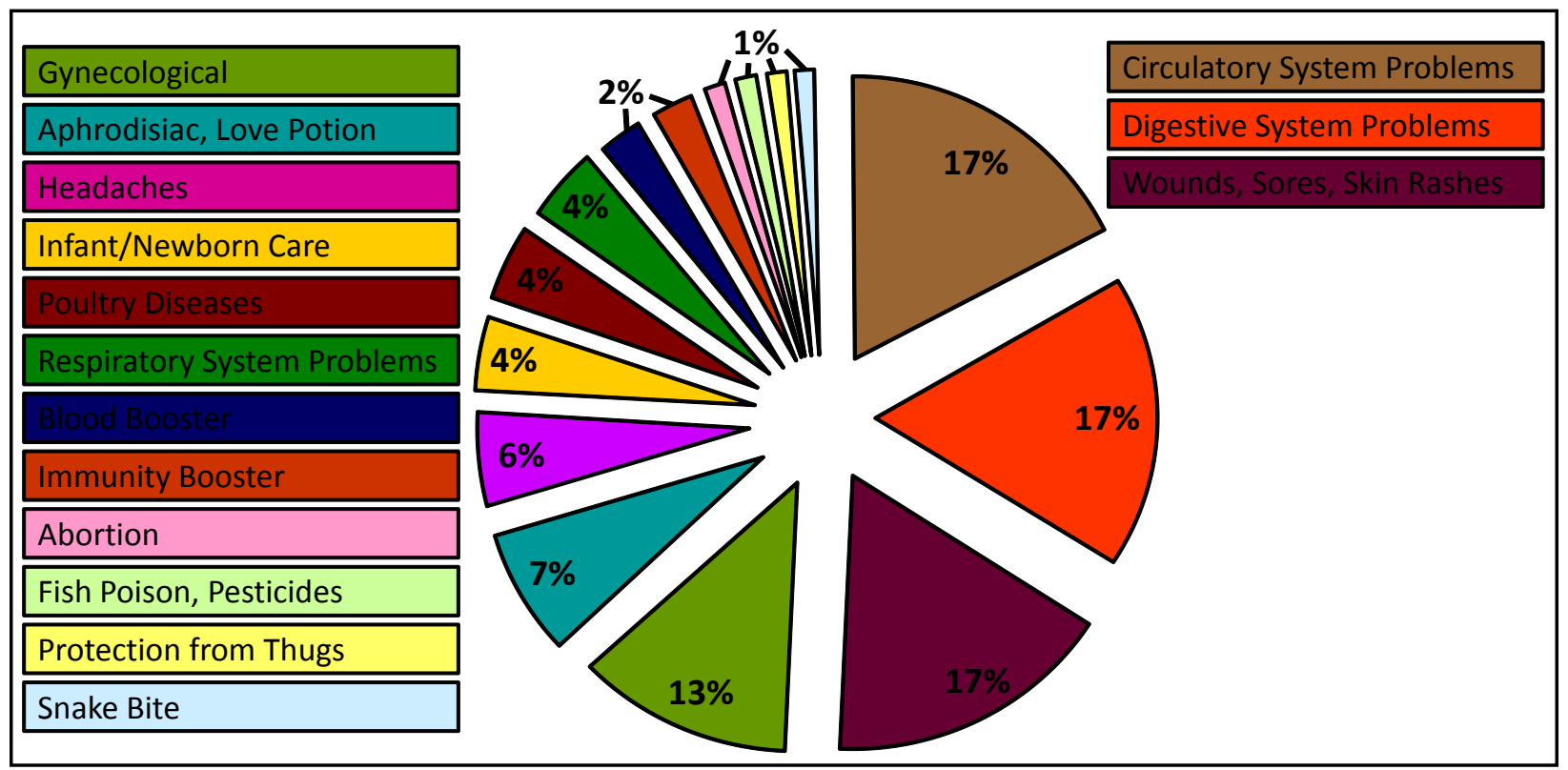

Figure 5. Medicinal geophytes identified by informants in Malawi sorted into major use categories. $n=71$ total uses. See Tables $1 \& 2$ for details of plants and uses. 
The local term mwana wa mphepo (Chichewa) which means "Child of the wind" is the common name referring to plant species and the diseases that they treat. In this study, the term was allocated to seven species, all vines, one, Adenia gummifera, in the Passifloraceae is introduced to Africa from South America. The other six are native African members of the Vitaceae family: Ampelocissus africana, Ampelocissus obtusata, Cissus aristolochiifolia, Cissus cornifolia, Cissus integrifolia, and Cyphostemma junceum. The traditional category of plant species is also known to treat different types of ailments as well (Tables $1 \& 2$ ). As a condition in the body, mwanamphepo (Chichewa, Lomwe), which is an abbreviation for mwana wa mphepo (Chichewa) refers to an upset stomach, stomach pains or sore skin.

\section{Other Uses}

Young boys used $L$. revoluta to catch insects. The bulb is ground and smeared close to where insects are flying and they get caught in the process. Dolichos kirimandscharicus and Neorautanenia mitis are used to treat poultry diseases such as Newcastle. Newcastle disease is a highly contagious zoonotic bird disease affecting many domestic and wild avian species. The disease is endemic in many countries including Malawi. In some parts of Malawi, $N$. mitis is also used as a fish poison and is known to kill a lot of fish when sprinkled in water.

\section{Trading of geophytes}

Half of the respondents also said that they sold the underground parts especially $D$. odoratissima which is an important famine food and $D$. anomala which is popular amongst herbalists and is sold as a single tuber or as a pile. In most cases these tubers are mixed with roots belonging to different species and processed into powder. These are then sold at a price of US\$7 (2006) per packet locally but the price varies when the powder is sold to foreigners (Dr. Kaunda personal communication).

\section{Method of harvesting and availability}

All respondents indicated that they harvested the tubers by digging with hoes Figure 6) or just uprooting (Figure 7). Geophyte digging is the most destructive kind of harvesting because it kills Mpalika) the whole plant. Most respondents indicated that in most cases the plant died after harvesting the tubers. $72 \%$ also indicated that tuber plant species have decreased if they compare with their availability now to five to ten years ago. Despite the apparent decrease in populations of geophytes, their domestication is not popular among the public because most believe that they grow naturally in forests and that they are difficult to cultivate. During the survey, most people said that they have seen some people, especially traditional healers, grow them around their yards; the major reason being easy access for their medicinal value.

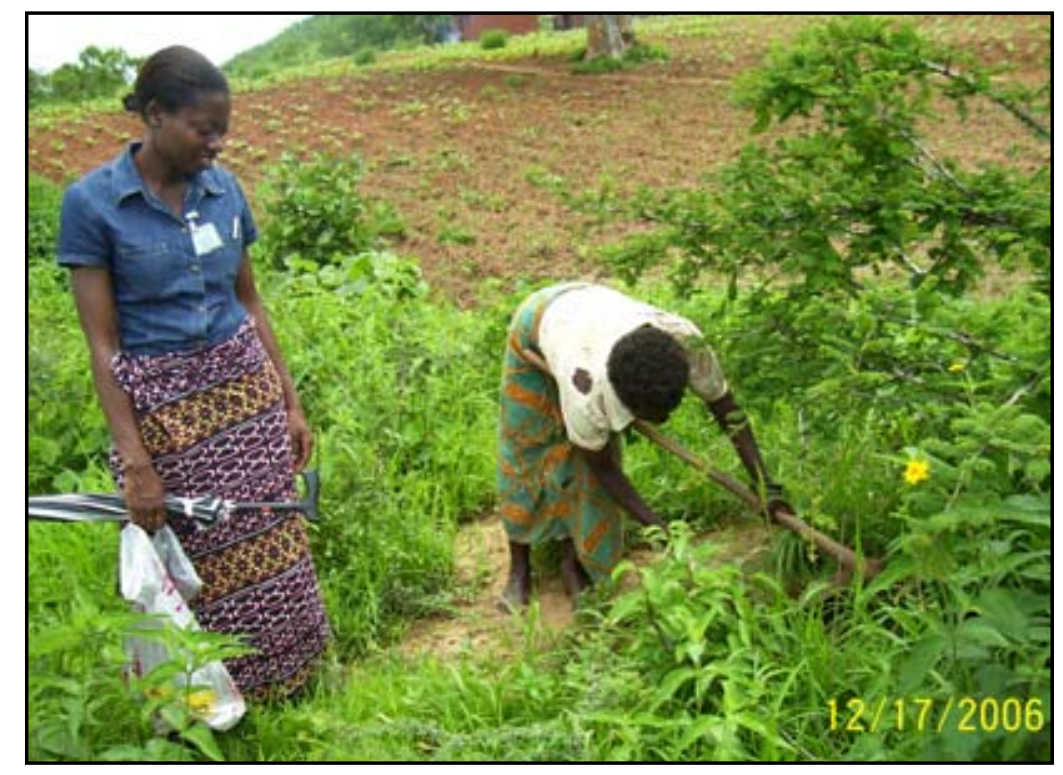

Figure 6. A respondent using a hoe to dig a tuber in Malawi. (Photo by D.

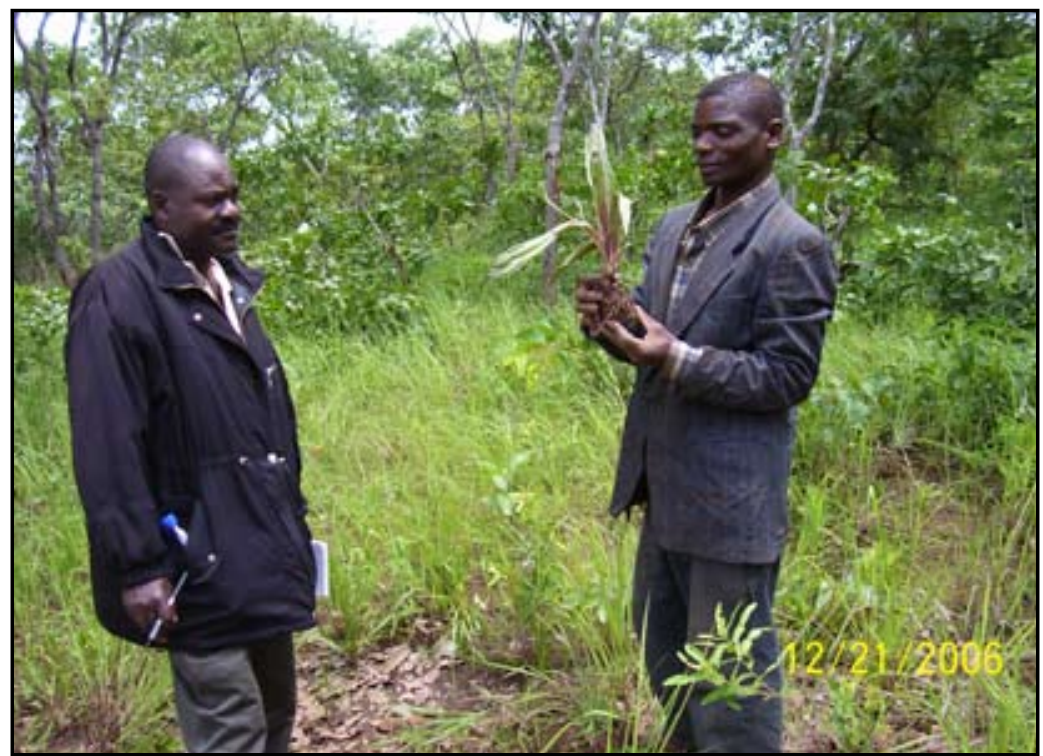

Figure 7. A respondent holding a Hypoxis species after uprooting it by hand in Malawi. (Photo by D. Mpalika) 


\section{Mwafongo et al. - Ethnobotanical Study of Hyacinthaceae and Non- hyacinthaceous Geophytes in Selected Districts of Malawi}

\section{Cluster analysis}

Figure 8 illustrates similarities of responses about geophyte species recorded in the 15 districts surveyed and reveals the existence of two groups (one consisting of Chikwawa district, the other of the remaining 14 districts) that are largely different, separating early in the dendrogram. Based on this cluster analysis, no districts are highly similar with each other and at most they form into seven groups with one, two or three districts each that are somewhat similar but each other still showing much distinctiveness. The division into groups is however not consistent with geography except in one instance: Thyolo and Mulanje are both from southern Malawi and are adjacent to each other.

\section{Species accumulation curve as a measure of sampling effort}

Figure 9 presents a species accumulation curve from the geophyte study of the 15 selected districts of Malawi.
The curve concludes with an upward trend indicating that sampling effort might have to be increased to accumulate more species (see Heck et al. 1975) in order to approach an asymptote.

\section{Estimating species richness from samples}

Figure 10 presents the performance of six non-parametric estimators of species richness compared with the species accumulation curve from the research. Since a good estimator of species richness is supposed to reach, or closely approach a stable horizontal asymptote sooner, i.e., with fewer samples, for this data set, Michaelis-Menten Means (MM Means) provided the least biased estimates based on small number of samples (ca. 2 samples) with Chao 2 a close second and ICE third. The rest of the estimators are rising parallel with the accumulation curve and seem to reach a horizontal asymptote after 15 samples. The MMMeans estimates generate the highest estimate (54 species) of species richness and Chao 2 the lowest estimate for the samples with 47 species. The bootstrap

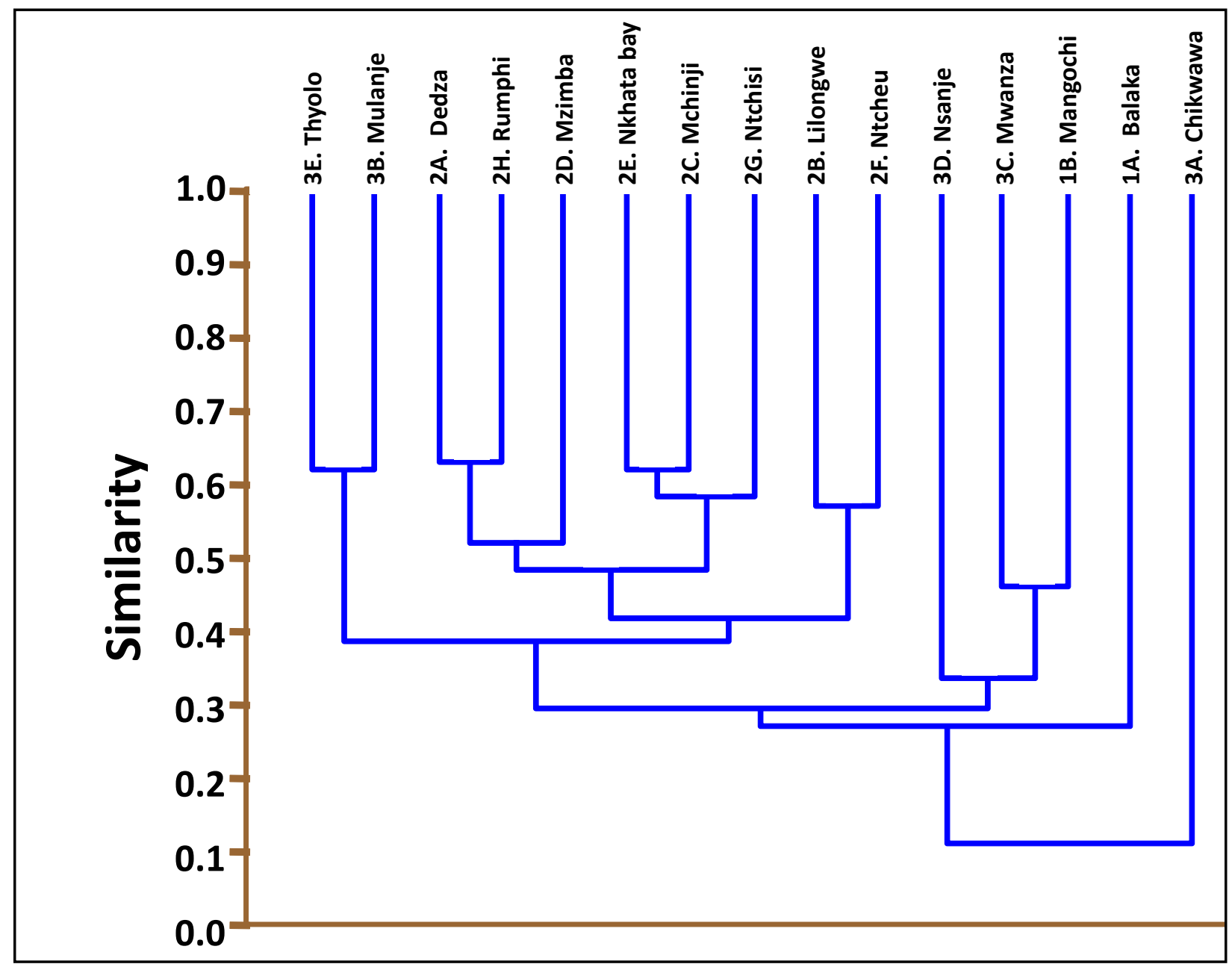

Figure 8. Phenogram cluster analysis with Sorensen Index based on presence/absence of geophyte species used in 15 districts surveyed in Malawi using PAST (Hammer \& Harper 2004). 


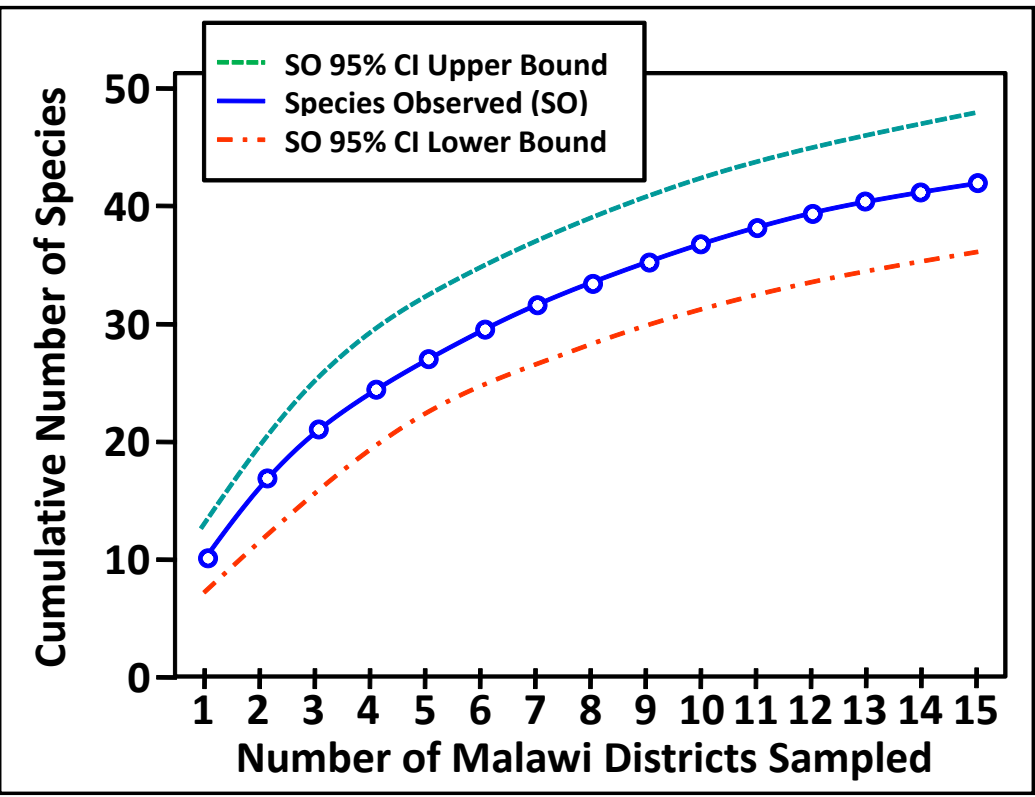

Figure 9. Species accumulation curve (middle curve) from a study of traditional use of geophytes in 15 selected districts of Malawi. Plotted with $95 \%$ confidence intervals (upper and lower curves). Analysis conducted using EstimateS (Colwell 2006).

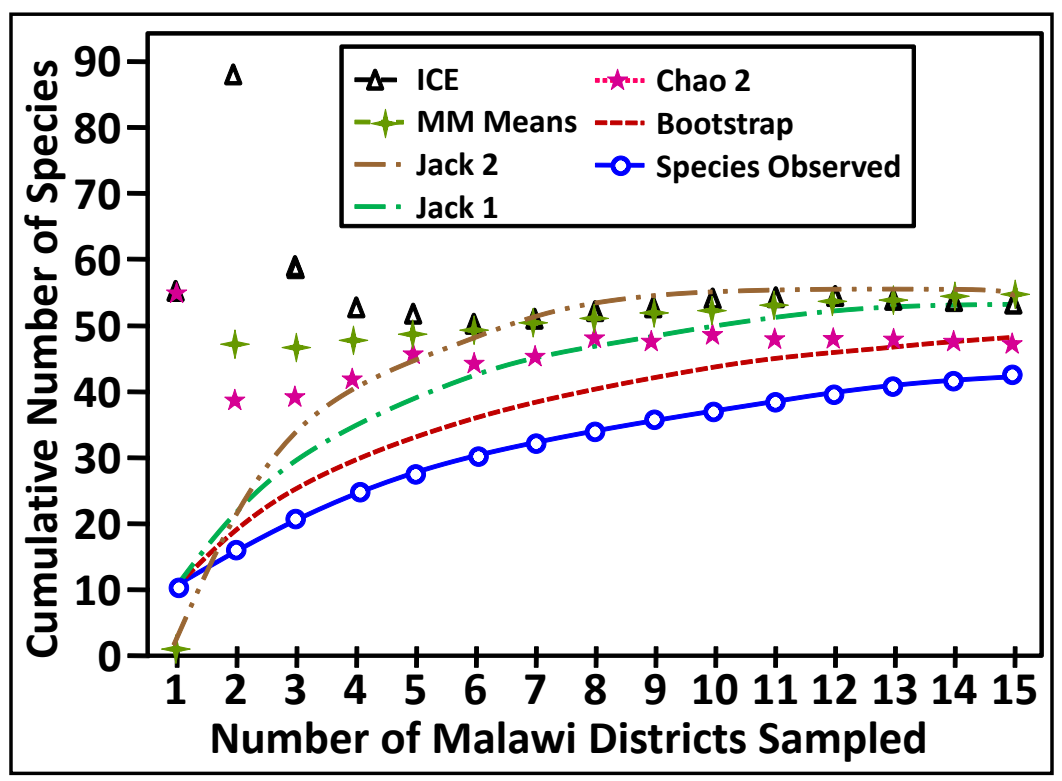

Figure 10. Species accumulation curve (species observed) from a study of traditional use of geophytes in 15 selected districts of Malawi compared with six non-parametric estimators of species richness (ICE, Chao 2, first order and second-order Jackknife, bootstrap and Michaelis-Menten Means) for the same data set. Descriptions and formulas of the species richness estimators used may be found in Colwell \& Coddington (1994). The sample order was randomized 100 times to compute the mean estimator and expected species richness for each sample accumulation level the end result of which was a smooth curve. Analysis conducted using EstimateS (Colwell 2006) and following the protocol of Williams et al. (2007). Estimators of species richness-non-parametric estimates were used since these require no assumptions of plant community structure. estimator however best approximated the known species richness followed by Chao 2.

\section{Discussion and Conclusions}

In the present study, members of the family Hyacinthaceae were less popular with only 3 species $(6 \%$ of the 49$)$ probably because people are spoilt with choices from other plants, both geophytes and non-geophytes, with which they could treat various diseases. In addition to this, we noticed that plants in the Hyacinthaceae were scarce in the field. This could be because most are low lying species growing in grasslands, hence they can be very cryptic. Although Hyacinthaceae were less popular in this study, members of the family have been documented elsewhere (Arnold et al. 2002) as being used for medicinal purposes ranging from the treatment of hangovers, rheumatic fever, sprains, syphilis, cancer, pneumonia the current study documented only 3 species of the family as being used as food and medicine Although the family is quite prominent in ethnomedicine, a few species have been chemically investigated so far (Louw et al. 2002). In addition to this, the family suffers from serious taxonomic problems and is in need of revision (Manning 2004, Stedje 1996).

This research has indicated that people use more underground parts that above ground parts of geophytes. The reason people say that they use more underground parts than leaves $(90 \%)$ is the fact that leaves are less bitter than tubers hence they believe that the concentration of the compounds is more in the tubers than in leaves.

Bulbous plants, though studied less intensively than herbs and trees regarding their medicinal potential, have proven to contain a range of unique biologically active compounds. The presence of steroids, cardiac glycosides and alkaloids in some species can often indicate toxicity. Several studies have documented poisoning with symptoms such as diarrhoea, abdominal pain, emphysema and increased pulse rate, which can be fatal (Louw et al. 2002, Van Wyk et al.1997). 


\section{Mwafongo et al. - Ethnobotanical Study of Hyacinthaceae and Non- hyacinthaceous Geophytes in Selected Districts of Malawi}

The present study similarly reports that bitter tubers used as food such as Dioscorea are boiled for long periods decanting water in the process of cooking to reduce the amount of poison. Similarly, species used as medicines are also diluted in water and taken in low doses because the respondents indicated that decoctions could prove to be fatal if taken in highly concentrated doses. The amount of poison is determined by tongue testing.

Dioscorea odoratissima is a famous famine food plant in most districts of Malawi and is also known to be rare. Members of this genus are also widely used around the world for both food and medicine. Wild yam species (e.g., Dioscorea villosa L. and Dioscorea batatas Decne.) have for centuries been used as sources of medicine and food by the Aztec and Mayan peoples for a wide range of ailments including many female problems and to relieve the pain of child birth (Bergeron 1997). The other famine food which is said to be rare is Nymphaea caerulea. Its tubers are known to have a higher calcium, phosphorus, and fatty acids (Chawanje 1998).

In this study, boiling of tubers used as food sources was very common and respondents said this act has a double function; enhancing the flavour of the tubers and reducing the poison which they contain. [This method is universally used around the world (Arnold et al. 2002, Banguar 1993).

Morris (1989) and Hargreaves (1994) identified 50 kinds of mwana wa mphepo and saw this category as not specific but referring to plants which store water and are able to produce flowers and leaves during the windy season. The problem with this definition is that not all such plants are mwana wa mphepo. This is probably why folk taxonomy is very difficult to adopt because it may represent different behavioral responses of people related to the salience of each organism (Hays 1982). Furthermore, Brown (1985) pointed out that people's vocabulary is related to their long-term interests. There is need to further research this term and see if indeed it is related to plant form and function or behavior of the people using the species included in this phenomenon. The term also contains unresolved species and hence more research into species delimitation and taxonomy is needed since certainty in species identification is a precondition for access to published species information related to, e.g., botany, ethnopharmacology, conservation and propagation (Krog et al. 2006). Proper species identification is also important in relation to consumer safety.

Species accumulation curves are known to enhance the value of ethnobotanical studies and create an opportunity for cogent arguments that advance scientific and practical knowledge (Williams et al. 2007). A comparative test of species estimators in the present study raises a question of survey sampling sufficiency because of failure of 4 out of 6 estimators to approach a horizontal asymptote. It is clear from these curves that more sampling was required and would have increased the species inventory.

The geophyte survey was driven by the need to document the use of Liliopsid monocots of family Hyacinthaceae and assess their conservation status. It is apparent from the survey that members of the Fabaceae and Asteraceae are more sought after for food and medicine than Lilioid monocots evidenced by fewer hyacinthoide representatives mentioned by respondents.

The most common anthropogenic pressure to all geophytes is tuber digging and clearing of woodlands for farming. The survey listed about 49 plant species that are most utilized. This number only represents a small proportion of all geophytes in Malawi. Some species were not reported here because they could not be spotted during field searches. Future work is therefore needed especially to go through the existing literature which will help generate new research ideas. Although this study has identified 49 geophytes from Malawi the actual number is not known. This problem is compounded by lack of a national checklist which usually acts as a guideline for such surveys. Support should also be provided for more taxonomic work in problematic genera, more ethnobotanical surveys and research towards sustainable use and conservation of these plants.

\section{Acknowledgements}

The current work was funded by the Norwegian Council for Higher Education's Programme for Development Research and Education (NUFU). Thanks is also due to Donald Mpalika, Edwin Kathumba and Moffat Thera (Herbarium Technicians) for helping with administering questionnaires and plant identification, the National Herbarium and Botanic Gardens of Malawi for providing transport and the driver and for helping out with all necessary field arrangements.

\section{Literature Cited}

Angiosperm Phylogeny Group. 2003. An update of the angiosperm phylogeny group classification for the orders and families of flowering plants: APG II. Botanical Journal of the Linnean Society 141: 399-436.

Anonymous. 1997. Population and Family Planning in Malawi: A community nexus approach. Government of Malawi and World Bank, Lilongwe.

Arnold, T.H., C.A.Prentice, L.C. Hawker, E.E. Snyman, M. Tomalin, N.R. Crouch, \& C. Pottas-Bircher. 2002. Medicinal and Magical Plants of Southern Africa: An annotated checklist. Strelitzia 13. National Botanical Institute, Pretoria, South Africa. 
Banquar, S.R. 1993. The role of traditional medicine in a rural medicine. Pp. 140-152 in Traditional Medicine in Africa. Edited by I. Sindinga, C. Nyaigatti-Chacha \& M.P. Kanunah. English Press Ltd, Nairobi.

BAA. 2008. Bureau of African Affairs. Background Note: Malawi. www.state.gov/r/pa/ei/bgn/7231.htm.

Bergeron, K. 1997. Medicinal Plants List. www.altnature. com/gallery/wild_yam.

Brown, C.H. 1985. Mode of subsistence and folk biological taxonomy. Current Anthropology 26:43-62.

Chawanje, C.M. 1998. Nutrient and antinutrient content of underexploited Malawian water tuber Nymphaea pepersiana Klotzsch. Ph.D. Dissertation. Virginia Polytechnic Institute and State University, Blacksburg, Virginia.

Colwell, R.K. \& J.A. Coddington. 1994. Estimating terrestrial biodiversity through extrapolation. Philosophical Transactions of the Royal Society (Series B) 345:101118

Colwell, R.K. \& J.A. Coddington. 1995. Estimating terrestrial biodiversity through extrapolation. Pp.101-118 in Biodiversity, Measurement and Estimation. Edited by D.L. Hawksworth. Chapman and Hall, London.

Colwell, R.K. 2006. EstimateS: Statistical estimation of species richness and shared species from samples. Version 7.5. www.purl.oclc.org/estimates.

Cunningham, A.B. 1993. African Medicinal Plants: Setting priorities at the interface between conservation and primary health care. People and Plants Working Paper 1. People and Plants Initiative, Division of Ecological Sciences, UNESCO, Paris.

Cunningham, A.B. 1994. Management of medicinal plant resources: An Africa-wide overview. 1:173-189 in Proceedings of the XIII Plenary Meeting of AETFAT, Zomba, Malawi, 2-11 April 1991. Edited by J.H. Seyani \& A.C. Chikuni. Association for the Taxonomic Study of the Flora of Tropical Africa, Brussels.

Dafni, A., D. Cohen, \& I. Noy-Meir. 1981. Life cycle variation in geophytes. Annals of the Missouri Botanical Garden 68:652-660.

Dahlgren, R.M.T. \& H.T. Clifford. 1982. The Monocotyledons: A comparative study. Academic Press, London. Dahlgren, R.M.T., H.T. Clifford \& P.F.Yeo. 1985. The Families of the Monocotyledons. Springer-Verlag, Berlin.

Dahlgren, R.M.T. \& F.N. Rasmussen.1983. Monocotyledon evolution: Character and phylogenetic analysis. Evolutionary Biology 16:255-395.
Engler, A. \& K. Prantl. 1930. Die Natiirhichen Pflanzen Familien. Volume 15a. Venlag von Wilhelm Engelmann. Leipzig.

Esler, K.J., P.W. Rundel \& P. Vorster. 1999. Biogeography of prostrate-leaved geophytes in semi-arid South Africa: Hypontheses of functionality. Plant Ecology 142:105-120.

Hagreaves, B.J. 1994. Mwana wa Mphempho. A traditional classification in Malawi. 1:239-249 in Proceedings of the XIII Plenary Meeting of AETFAT, Zomba, Malawi, 2-11 April 1991. Edited by J.H. Seyani \& A.C. Chikuni. Association for the Taxonomic Study of the Flora of Tropical Africa, Brussels.

Hammer, Ø. \& D.A.T. Harper. 2004. PAST: PAlaeontological STatistics. Version 1.29. http://folk.uio.no/ohammer/ past.

Hardcastle, P.D. 1977. A Preliminary Silvicultural Classification of Malawi. Forestry Research Record NO. 57. Forestry Research Institute of Malawi. Government Press, Zomba.

Hays, T.E. 1982 Utilitarian/adaptionist explanations of folk biological classification: Some cautionary notes. Journal of Ethnobiology 2:89-94.

Heck, K.L., G. van Belle \& D. Simberloff. 1975. Explicit calculation of the rarefaction diversity measurement and the determination of sufficient sample size. Ecology $56: 1459-1461$

Höft, M., S.K. Barik., \& A.M. Lykke. 1999. Quantitative Ethnobotany: Applications of multivariate and statistical analyses in ethnobotany. People and Plants Working Paper 6. People and Plants Initiative, Division of Ecological Sciences, UNESCO, Paris.

Krog, M., M. P. Falcão \& C.S. Olsen, 2006. Medicinal Plant Markets and Trade in Maputo, Mozambique. Working Papers No. 16-2006 Development \& Environment. Danish Centre for Forest, Landscape and Planning Hørsholm, Denmark. www.sl.kvl.dk/upload/workingpapersno16.pdf

Louw, C A. M, T. J. C. Regnier \& L. Korsten. 2002. Medicinal bulbous plants of South Africa and their traditional relevance in the control of infectious diseases. Journal of Ethnopharmacology 82:147-154.

Maliwichi, C.P. 1997. Trade in Wildlife Medicinals in East and Southern Africa - Malawi Component. Report prepared for TRAFFIC East/Southern Africa. Nairobi, Kenya.

Manning, J. 2004. Family: Hyacinthaceae. www.plantzafrica.com/planthij/hyacinth.htm 


\section{Mwafongo et al. - Ethnobotanical Study of Hyacinthaceae and Non- hyacinthaceous Geophytes in Selected Districts of Malawi}

Morris, B. 1989. Medicines and herbalism in Malawi. The Society of Malawi Journal 42:34-54.

Morris, B. \& J.D. Msonthi. 1991. Medicinal Plants of Malawi. Goldsmiths College, London

Morris, B. \& J.D. Msonthi. 1996. Chewa Medical Botany. A study of herbalism in Southern Malawi. Part 2. Medicinal plants of Malawi. International African Institute, London.

Mpaka, C. 2008. Whether it is about floods or handouts. Daily Times Newspaper. 31st January. Blanytre Newspapers Ltd, Blantyre, Malawi.

Msekandiana, G. \& E. T. Mlangeni. 2002. Malawi. Pp. 31 42 in Southern African Plant Red Data Lists. Edited by J.S. Golding. Southern African Botanical Diversity Network Report No. 14. SABONET, Pretoria.

Msonthi, J.D.1994. Research into medicinal plants of Malawi.1:173-189 in Proceedings of the XIII Plenary Meeting of AETFAT, Zomba, Malawi, 2-11 April 1991. Edited by J.H. Seyani \& A.C. Chikuni. Association for the Taxonomic Study of the Flora of Tropical Africa, Brussels.

Msonthi, J.D. \& J.H. Seyani. 1994. Research into Medicinal Plants of Malawi. 1:223-231 in Proceedings of the XIII Plenary Meeting of AETFAT, Zomba, Malawi, 2-11 April 1991. Edited by J.H. Seyani \& A.C. Chikuni. Association for the Taxonomic Study of the Flora of Tropical Africa, Brussels.

Mwanyambo, M.L. 1994. Non-medicinal plant uses of the Nyakyusa, Lower Songwe Valley, Karonga, Malawi. 1:7588 in Proceedings of the XIII Plenary Meeting of AETFAT, Zomba, Malawi, 2-11 April 1991. Edited by J.H. Seyani \& A.C. Chikuni. Association for the Taxonomic Study of the Flora of Tropical Africa, Brussels.

Mwanyambo, M.L. \& D.A. Nihero. 1998. Medicinal Plants and Biodiversity Project. International Development Research Centre, Final Technical Report, Nairobi.

Mwanyambo, M.L. \& S.I. Kananji. 2001. Wild yams kill: Which ones? The Nation. Nation Publications Ltd, Blantyre. Malawi, 18th January.

Ncube, J. 1998. African potato offers hope for sufferers. Horizon Magazine (Harare). Pp.12-13.
Ndibwami, A., E. Henry \& J.D.K. Saka. 1998. Traditional Medicine in Malawi: Altitudes, practices, problems, and constraints. A working document for a workshop held at Chancellor College, Zomba, Malawi. 25-26 March, 1998.

NSO, 1992. National Statistics Office. Malawi: Demographic and Health Survey. National Statistic Office, Zomba, Malawi.

Pohl, T.S., N.R. Crouch \& D.A. Mulholland. 2000. Southern African Hyacinthaceae: Chemistry, bioactivity and ethnobotany. Current Organic Chemistry 4:1287-1324.

Sneath, P.H.A. \& R.R. Sokal. 1973. Numerical Taxonomy: The principles and practice of numerical classification. W.H. Freeman \& Co. San Fransisco.

Stedje, B. 1996. Flora of Tropical East Africa. Hyacinthaceae. Edited by R.M. Polhill. A.A. Balkema, Rotterdam.

Stevens, P.F. 2001 onwards. Angiosperm Phylogeny Website. Version 9, June 2008 [and more or less continuously updated since]. www.mobot.org/MOBOT/research/ APweb/.

Van Wyk, B., B. Van Oudtshoorn \& N. Gericke 1997. Medicinal Plants of South Africa. Briza, Pretoria.

White, F. 1976. The vegetation Map of Africa:The history of a completed project. Boissiera 24:659-666.

White, F., F. Dowsett-Lemaire \& J.D. Chapman 2001. Evergreen Forest Flora of Malawi. Royal Botanical Garden, Kew.

Williams, V.L., E.T.F. Witkowski \& K. Balkwill. 2007. The use of incidence-based species richness estimators, species accumulation curves and similarity measures to appraise ethnobotanical inventories from South Africa. Biodiversity \& Conservation 16:2495-2513.

Williamson, J. 1974. Useful Plants of Malawi. University of Malawi, Zomba. Revised and extended edition, Montfort Press, Limbe, Malawi. 
